Gi respons på artikler gjennom artiklenes kommentarfelt på tidsskriftet.no.

Innleggene publiseres fortløpende på Tidsskriftets nettside og et utvalg

av innleggene publiseres også i papirutgaven i spalten «Brev til redaktøren».

Redaksjonen forbeholder seg retten til å foreta redaksjonelle endringer.

Forfattere av vitenskapelige artikler har tilsvarsrett, jf. Vancouver-gruppens regler.

\section{Re: Akuttmottaket trenger egne spesialister}

Bjørnsen og Uleberg fortsetter å kjempe for ny spesialitet i akuttmedisin (1). Det er vanskelig å se at det er ny medisinsk utvikling som skaper dette behovet. Etter min mening er det snarere dårlig organisering av våre akuttmottak som gjør at de trenger å styrkes. Akkurat der er vi enige. Men løser vi det ved å etablere en ny spesialitet? Neppe.

Som anestesiolog gjennom 25 år på et akuttsykehus med traumefunksjon, langt fra andre sykehus, ser jeg ikke noe behov for nye spesialister i akuttmottak. Helsetilsynet var tydelige på hva som manglet i tilsynsrapporten fra 2008 (2). De foreslo tiltak som kan gjennomføres med vilje, arbeidstilrettelegging og fleksibilitet med dagens spesialister. I Finnmark har vi flinke spesialister i allmennmedisin som vurderer pasientene godt før innleggelse, og som konfererer med sykehusets leger. Hverken medisinske pasienter eller traumepasienter trenger enda en spesialitet på akuttsykehusene, og den foreslåtte spesialitet blir antakelig vanskelig å rekruttere til for å sortere noen få, allerede vurderte og triagerte pasienter hvert døgn. Dette ble også konklusjonen i en nasjonal arbeidsgruppes utredning som ble levert i 2008 (3). Dessverre har Bjørnsen og Uleberg ikke vist til den.

Som leder for Nasjonal Kompetansetjeneste for Traumatologi tror jeg ikke akuttmedisin vil tilføre alvorlig skadde pasienter noe sykehusenes traumeteam ikke allerede tilbyr. Tvert imot, det kan bli et forsinkende ledd. Vi har vist at sykehusene med traumefunksjon stort sett allerede fyller kravene til kompetanse og organisering (4), et eksempel som viser at det er mulig å organisere gode pasienttilbud med dagens spesialiteter, men også at det er behov for regelmessig oppbygging av kompetanse. En ny spesialitet kan etter mitt syn ikke tilføre slik kompetanse.

Bjørnsen og Uleberg skylder norske pasienter en forklaring på hva denne eventuelle nye spesialitet skal tilføre som ikke allerede finnes, og hvorfor landets sykehus i tilfelle skal bruke sine knappe midler på enda et vaktlag, hvert døgn, året rundt, når tilsvarende kompetanse allerede finnes både i primærhelsetjenesten og på sykehusene. Norsk selskap for akuttmedisin kjemper for et behov som ikke er pasientens eller sykehusenes.

\section{Torben Wisborg}

torben.wisborg@traumatologi.no

Torben Wisborg (f. 1956) er overlege ved Akuttavdelingen, Hammerfest sykehus, Finnmarkssykehuset HF, professor ved Universitetet i Troms $\varnothing$ og leder for Nasjonal Kompetansetjeneste for Traumatologi, OUS HF. Ingen oppgitte interessekonflikter.

\section{Litteratur}

1. Bjørnsen LP, Uleberg O. Akuttmottaket trenger egne spesialister. Tidsskr Nor Legeforen 2015; 135: $1230-2$

2. Helsetilsynet. «MENS VI VENTER ...»-forsvarlig pasientbehandling i akuttmottakene? Rapport fra Helsetilsynet 2/2008. https://helsetilsynet.no/upload/ publikasjoner/rapporter2008/helsetilsynetrapport2 2008.pdf (16.8.2015)

3. Bjelke C, Breidablikk HJ, Johansen K et al. Utredning av en evt. ny spesialitet i akuttmedisin - et interregionalt prosjekt. Bodø. Helse Nord 2008. www.helse-nord.no/getfile.php/RHF\%2OINTER/RAPPORTER\%20OG\%20H\%C3\% 98RINGER/Utredning\%20om\%20ny\%20spesialitet $\% 20 i \% 20$ akuttmedisin $\% 20$ endelig\%20rapport.pdf (16.8.2015).

4. Dehli T, Gaarder T, Christensen BJ et al. Implementation of a trauma system in Norway: a national survey. Acta Anaesthesiol Scand 2015; 59: 384-91.

\section{Re: Alder og alvor}

Bjarne Robberstads drøfting av alder og alvor (1) er teknisk interessant, men jeg mener han skaper forvirring ved ikke å skille mellom hva et godt etablert uttrykk som «en tilstands alvorlighet» betyr i medisin og hvilken vekt man kan ønske å legge på ulike hensyn ved prioritering.

Helse- og omsorgsdepartementet har fra en arbeidsgruppe under ledelse av professor Jon Magnussen bestilt en vurdering av gjeldende prioriteringskriteriers alvorlighetsbegrep og mulig operasjonalisering av dette. Da må vi til Lønning 2. Det er klart, som Robberstad påpeker, at langvarig lidelse er mer alvorlig enn kortvarig lidelse (for eksempel kyssesyke vs influensa). Men det er også klart at gjenstående levetid ikke inngår i Lønning 2's alvorlighetsbegrep. Det følger av Lønning 2's klare standpunkt om at alder/gjenstående levetid ikke skal være et selvstendig prioriteringskriterium.

Man kan diskutere i det vide og det brede nøyaktig hvilke aspekter alvorlighetsbegrepet $\mathrm{i}$ dag rommer, men et enkelt sett av faktiske observasjoner er kanskje vel så hensiktsmessig for å få skilt lort fra kanel. Jeg nøyer meg med følgende fire:

A Når 40-åringer og 70-åringer får livstruende sykdom:

Dagens språk: De regnes som like alvorlig syke.

Prioritet: De får samme prioritet for livreddende kirurgi - også om den er svært kostbar.

B Når 50-åringer og 80-åringer får like sterk kronisk smerte: Dagens språk: De regnes som like alvorlig syke.

Prioritet: De møter samme betalingsvillighet for smertedempende legemiddel på blåresept.

C Når en 60-åring og en 80-åring får sykdommer som forventes å redusere førstnevntes gjenstående levetid fra 20 til 10 og sistnevntes fra 6 til 3 år:

Dagens språk: De regnes som like alvorlig syke.....

Prioritet: ... men betalingsvilligheten for behandling er trolig likevel større for 60-åringen ut fra en tanke om at 80-åringen «har fått sitt beger rimelig oppfylt».

D Når en 20-åring og en 90-åring er i livstruende tilstand: Dagens språk: De regnes som like alvorlig syke.....

Prioritet: ... men 20-åringen får prioritet / møter større betalingsvillighet.

Relativt prognosetap, som Robberstad nevner som målebegrep nummer 5, er en operasjonalisering av alvorlighet som ivaretar denne språklige forståelsen, i det den gir samme skåre for de to gruppene i hvert av eksemplene ovenfor. Som mål på alvorlighet bryter absolutt prognosetap med denne språkforståelsen i alle de fire eksemplene. Det blir som i regresjonsanalyse, dette: Man undersøker hvilken modell - her hvilken definisjon - som gir best tilpasning til data.

Når det gjelder prioritering, vil prioritering etter relativt prognosetap være konsistent med prioriteringene i dag i eksemplene A og B. Prioritering etter absolutt prognosetap tilsier endret praksis, nemlig at de yngre skal prioriteres. Å vektlegge relativt prognosetap alene vil ikke fange opp prioriteringene $\mathrm{i}$ eksemplene $\mathrm{C}$ og D. Men alder/gjenstående levetid som tilleggskriterium til alvorlighet målt som relativt prognosetap vil kunne ivareta prioriteringsverdien «oppfylt beger» i de situasjoner og i den grad dette er ønskelig (eksemplene C og D). 
Det er i prinsippet selvsagt mulig å vurdere nye måter å bruke ordet alvorlighet på heretter, og tilhørende operasjonaliseringer. For eksempel kan man gå inn for at i eksemplene A og B skal heretter 40-åringene sies å være mer alvorlig syke enn 70-åringene. Da blir absolutt prognosetap en egnet operasjonalisering av alvorlighet. Men da er det ikke bare salige Inge Lønnings språk man vil forandre, men også språket til klinikere og folk flest. Det er en tung og uhensiktsmessig vei å gå, og etter min mening respektløst overfor etablert språk. Vil man ha større vekt på alder og gjenstående levetid ved prioritering, er det bedre å ta dem inn som separate tilleggskriterier enn å gi seg til å tukle med språket. Ved å holde begrepene og kriteriene adskilt får man også den nødvendige frihetsgraden til å bestemme presist i hvilke konkrete sammenhenger og hvor sterkt alder og gjenstående levetid skal vektlegges, jfr for eksempel forskjellen på $\mathrm{A}$ og $\mathrm{B}$ vs $\mathrm{C}$ og $\mathrm{D}$.

\section{Erik Nord}

Erik.Nord@fhi.no

Erik Nord (f. 1948) er seniorforsker ved Nasjonalt folkehelseinstitutt og professor i helseøkonomi ved Universitetet i Oslo. Ingen oppgitte interessekonflikter.

\section{Litteratur}

1. Robberstad B. Alder og alvor. Tidsskr Nor Legeforen 2015; 135: 1376-8.

\section{B. Robberstad svarer:}

Erik Nord gir uttrykk for at «en tilstands alvorlighet» i dag er eit godt etablert uttrykk. Dette har eg til gode å høyre frå personar som har forsøkt å operasjonalisere det i praksis. Uttrykket ser ikkje ein gong ut til å vere spesielt godt etablert hos Erik Nord. Her tek han til orde for å definere alvor som relativt framtidig tap av helse (definisjon iv eller v i min kronikk), i kombinasjon med alder. Tidlegare har han argumentert for både definisjon (i) og (iii) (1). Desse alternativa kan implisere høgare prioritet for sjukdom som rammar eldre enn tilsvarande sjukdom for yngre (iii, v eller vi), eller bety at vi ved vurdering av alvor skal sjå heilt vekk frå varigheten av sjukdom (i). Ein konsekvens av desse alternativa er høgare prioritet til marginal livsforlenging på slutten av livet på bekostning av tiltak for kronikarane.

Nord foreslår å vurdere alvorlighetsmodell med hjelp av ei regresjonsanalytisk tilnærming, for å sjå kva modell som passer best til data. Han konstruerer deretter fire «observasjonar» som han meiner viser at alvorlighet vurdert som absolutt tap av gode leveår bryt med "språkforståelse», medan relativt framtidig helsetap ikkje gjer det. Regresjonsanalyse kan gi underlege resultat når observasjonane er få og selekterte. Eg meinar Nord sine eksempel A og B har liten relevans for denne debatten. Desse pasientgruppene har alle høg prioritet, både med eksisterande, tidlegare og føreslåtte nye prioriteringskriterier. Her er det ingen dilemma og ingen diskurs. Det vil vere nyttig for debatten om ein sluttar å antyde at 70-åringar med livstruande sjukdom eller 80-åringar med sterke smerter ikkje lenger skulle få behandling. Diskusjon av prioritet er best å gjere på «marginen», altså i situasjonar der det faktisk kan vere aktuelt å seie nei til behandling fordi den ikkje er tilstrekkeleg nyttig, fordi den er for ressurskrevjande, eller fordi den ikkje gjeld alvorleg nok sjukdom til å prioriterast framfor andre tiltak.

Eksempel C og D er langt meir interessante i så måte. Det finst sjølvsagt ingen «korrekte» preferansar om desse spørsmåla, men eg er grunnleggande usamd med Nord i at det er like alvorleg for ein 80-åring å miste tre leveår, som for ein 60-åring å miste 10 leveår. Eg er også usamd $i$ at det skulle vere like alvorleg med livstruande sjukdom for ein 90 -åring som for ein 20 -åring. Her har vi ulike preferanser, òg ulik språkforståing.

Erik Nord nyttar Inge Lønning som sannhetsvitne for eigne preferanser og språkforståing. Som teolog er det mogleg at Lønning hadde over gjennomsnittleg sans for profetiske nådegaver. Men det er vanskeleg å skjøne logikken når Erik Nord profetisk tolkar Løn- ning 2's runde definisjon av alvor som brøken av helsetapet med sjukdom over gjenverande helse i mangel av sjukdom på diagnosetidspunktet. Ordet «relativt prognosetap» er nemleg ikkje nemnt i Lønning 2's rapport (2), og rapporten er fri for tekniske presiseringar i denne retningen. Tvert om er det presisert (s. 189) at «Utvalget finner det riktig å påpeke at den offentlige helsetjenesten har et særlig ansvar for de kronisk syke». Nords alvorlighetspreferanser representerer lågare prioritet til desse pasientane, medan helsetapskriteriet ville styrke den.

Nord bør også slutte å kritisere «alder/gjenstående levetid som selvstendig prioriteringskriterium». Det er nemleg ingen som foreslår dette, sjølv om pressedekning kan gi inntrykk av det motsette (3). Helsetapskriteriet seier rett og slett at stor sjukdomsbyrde er meir alvorleg enn mindre sjukdomsbyrde. I staden for å repetere slike unøyaktigheter bør vi fokusere på å greie ut etiske implikasjonar av alternativa, og å undersøke betre korleis dei samsvarer med allmenn intuisjon.

Gode «aldersnøytrale» definisjonar for alvor eksisterer ikkje. Eitt sentralt spørsmål vert då om eldre si helse indirekte skal prioriterast opp, slik Nord sitt forslag kan implisere, eller om vi heller indirekte skal prioritere langvarig sjukdom som rammer unge, som er ein av konsekvensane av Norheimutvalet sitt forslag.

\section{Bjarne Robberstad}

Bjarne.robberstad@uib.no

Bjarne Robberstad (f. 1965) er professor i helseøkonomi ved Universitetet i Bergen.

Oppgitte interessekonflikter: Han er kollega med Ole Frithjof Norheim og har vore forfattar saman med han ved fleire høve.

\section{Litteratur}

1. Nord E. Prioriteringsutvalgets innstilling (NOU 2014: 12). www.regjeringen.no/ contentassets/0d5981f2343b41b1993146d58c229b07/erik-nord.pdf (1.9.2015)

2. Prioritering på ny. (NOU 1997: 18). www.regjeringen.no/no/dokumenter) nou-1997-18/id140956/?ch=1 (1.9.2015).

3. Dommerud T. Alder blir ikke avgjørende for behandling. Aftenposten 16.6. 2015 www.aftenposten.no/nyheter/iriks/Alder-blir-ikke-avgjorende-for-behandling8060667.html (1.9. 2015).

\section{Re: Alkoholforbruk - en naturlig del av anamnesen}

«Spørsmål omkring bruk av nikotin og alkohol bør være en naturlig del av anamneseopptaket...» hevdes det i en kommentarartikkel i Tidsskriftet (1). Jeg vil komme med et lite råd til dem som skal stille spørsmål om alkoholforbruk. I stedet for å spørre «drikker du?» kan det være lettere å svare ved å skulle plassere seg på en skala fra 0 til 10. Dette kan brukes for alle spørsmål som er litt personlige. Man føler seg mindre angrepet enn hvis «du» er et viktig ord i spørsmålet.

\section{Kirsten Osty \\ osty@orange.fr \\ Kirsten Osty (f. 1947). \\ Ingen oppgitte interessekonflikter \\ Litteratur \\ 1. Kristensen $\emptyset$. Vederhus J-K. Alkoholforbruk - en naturlig del av anamnesen. Tidsskr Nor Legeforen 2015; 135: 1240-1.}

\section{$\emptyset$. Kristensen svarer:}

Kristen Osty foreslår i sin kommentar en indirekte måte å spørre om alkoholbruk på, en måte som hun mener er mindre provoserende. Takk for tipset! Det er mange måter å innlede en samtale om alkoholbruk i medisinsk sammenheng, og det går sikkert an å finne sin personlige vri. 